\title{
Rhizospheric activity of phytoremediation species in soil contaminated with picloram ${ }^{1}$
}

Wendel Magno de Souza ${ }^{2}$, Fernanda Aparecida Rodrigues Guimarães², Matheus de Freitas Souza ${ }^{2}$, Daniel Valadão Silva ${ }^{3}$, Christiane Augusta Diniz Melo ${ }^{4}$

\section{ABSTRACT}

Some plant species have the ability to stimulate the microbiota activity in the rhizosphere and thereby increase the herbicide degradation in the soil. This study aimed at evaluating the microbial activity of soils contaminated with picloram and pre-cultivated with phytoremediation species. The experimental design was completely randomized, with three replicates. The treatments were organized in a $5 \times 2$ factorial scheme, with the first factor being the types of cultivation (autoclaved and non-autoclaved soil without cultivation and soil from the rhizosphere of Urochloa brizantha, Panicum maximum and Zea mays) and the second factor referring to the absence or presence $\left(240 \mathrm{~g} \mathrm{ha}^{-1}\right)$ of picloram. The evolved C-CO ${ }_{2}$, microbial biomass carbon and metabolic quotient were estimated. The herbicide altered the evolved C-CO, however, it did not affect the microbial biomass carbon and the metabolic quotient in the rhizospheric soils of the species. The cultivation of Zea mays increased the rhizosphere activity. The three plant species affect the soil microbial activity, however, the cultivation of Panicum maximum and Urochloa brizantha cause a lower disturbance on the microbial population, if compared to Zea mays. The picloran application does not affect the biological quality of the soils studied.

KEYWORDS: Phytoremediation; herbicide; rhizosphere; respirometry.

\section{INTRODUCTION}

Picloram (4-amino-3,5,6-trichloro-2pyridinecarboxylic acid) is widely used to control dicotyledon weeds in pastures (Silva \& Silva 2007). This herbicide can persist in the soil for years, due to its residual long effect, intoxicating crops in succession, such as soybean, bean and cotton (D'antonino et al. 2009). Besides that, the picloram waste may accumulate in soil and water resources (Pareja et al. 2012, Delwiche

\section{RESUMO}

Atividade rizosférica de espécies

fitorremediadoras em solo contaminado com picloram

Algumas espécies de planta têm a capacidade de estimular a atividade da microbiota na rizosfera e, com isso, aumentar a degradação de herbicida no solo. Objetivou-se avaliar a atividade microbiana de solos contaminados com picloram e pré-cultivados com espécies fitorremediadoras. $\mathrm{O}$ delineamento experimental utilizado foi inteiramente casualizado, com três repetições. Os tratamentos foram organizados em esquema fatorial $5 \times 2$, sendo o primeiro fator constituído por tipos de cultivo (solo sem cultivo autoclavado e não autoclavado e solo da rizosfera de Urochloa brizantha, Panicum maximum e Zea mays) e o segundo consistindo da ausência ou presença $\left(240 \mathrm{~g} \mathrm{ha}^{-1}\right)$ de picloram. Estimaram-se o C- $\mathrm{CO}_{2}$ evoluído, o carbono da biomassa microbiana e o quociente metabólico. O herbicida alterou o C- $\mathrm{CO}_{2}$ evoluído, mas não alterou o carbono da biomassa microbiana e o quociente metabólico nos solos rizosféricos das espécies. O cultivo de Zea mays aumentou a atividade da rizosfera. As três espécies de planta afetam a atividade microbiana do solo, no entanto, o cultivo de Panicum maximum e Urochloa brizantha causam menor perturbação na população microbiana, em comparação a Zea mays. A aplicação de picloran não afeta a qualidade biológica dos solos estudados.

PALAVRAS-CHAVES: Fitorremediação; herbicida; rizosfera; respirometria.

et al. 2014), causing negative effects in the soil biota and ground and surface waters through surface runoff and leaching (Sarmah et al. 2004, Belo et al. 2011).

Phytoremediation is an alternative to reduce the residual effect of picloram in the soil, which is based on the cultivation of plants capable of reducing the concentration of toxic compounds in the environment (soil and water) through phytodegradation or phytostimulation of the microbiota (White \& Newman 2011).

1. Manuscript received in Sep./2016 and accepted for publication in Apr./2017 (http://dx.doi.org/10.1590/1983-40632016v4743289).

2. Universidade Federal de Viçosa, Departamento de Fitotecnia, Viçosa, MG, Brazil. E-mails: wendelsouzaagro@gmail.com, fernanda.guimaraes@ufv.br, freitasouza@yahoo.com.br.

3. Universidade Federal Rural do Semiárido, Departamento de Fitotecnia, Mossoró, RN, Brazil. E-mail: danielvaladaos@yahoo.com.br. 4. Universidade Federal de Viçosa, Departamento de Fitotecnia, Rio Paranaíba, MG, Brazil. E-mail: chrisadinizmelo@yahoo.com.br. 
Rhizospheric regions are characterized by an intense microbiological activity, and can support the growth of microbial populations up to 100 times higher than in non-rhizospheric regions (Moreira \& Siqueira 2002, Fernandez et al. 2009). Besides that, the root exudates of plants determine the microbial composition of the rhizosphere, varying according to the plant species and age (Costa et al. 2000), as well as other factors such as plant exposure to toxic compounds and soil type (Fernandez et al. 2009, White \& Newman 2011).

Studies have demonstrated the capacity of some plants, such as Urochloa brizantha, Urochloa decumbens, Panicum maximum, Eleusina coracana and Zea mays, to reduce the picloram concentration in contaminated soils (Carmo et al. 2008, Oliveira et al. 2008, Assis et al. 2010, Franco et al. 2014). These plants can accelerate the picloram microbiological degradation. In addition, they can also extract this herbicide from the soil and accumulate it in roots and leaves (Santos et al. 2007 and 2010, Fernandez et al. 2009). The evaluation of the microbial activity in the rhizosphere is a tool used to infer the role of the microbiota in herbicide remediation. This activity can be estimated indirectly by different variables, such as soil respiration, microbial biomass carbon and metabolic quotient $\left(q \mathrm{CO}_{2}\right)$, and these methods are common in studies involving soils contaminated with herbicides (Pires et al. 2005a, Santos et al. 2007 and 2010, Reis et al. 2008).

Several plant species with capacity of remediating soils contaminated with picloram have already been identified. However, the impacts of this herbicide on the rhizospheric microorganisms that are associated with the roots of these plants are unknown. Thus, this study aimed at evaluating the microbiological activity associated with the rhizosphere of species used in the remediation of soils contaminated with picloran.

\section{MATERIAL AND METHODS}

The experiment was carried out in a greenhouse and a laboratory of the Universidade Federal de Viçosa, in Viçosa, Minas Gerais State, Brazil, in November 2013. The soil used was classified as a typical Dystrophic Red-Yellow Oxisol (56\% of clay, $6 \%$ of silt and $38 \%$ of sand), in an area under degraded pasture. The soil chemical analysis demonstrated $\mathrm{pH}\left(\mathrm{H}_{2} \mathrm{O}\right)$ of 5.3; organic matter content of $3.5 \%$; $\mathrm{P}$ and $\mathrm{K}$ of $47.4 \mathrm{mg} \mathrm{dm}^{-3}$ and $98 \mathrm{mg} \mathrm{dm}^{-3}$ (Mehlich ${ }^{-1}$ extractor), respectively; Ca, $\mathrm{Mg}, \mathrm{Al}$ (extractor $\mathrm{KCl} 1 \mathrm{~mol} \mathrm{~L}^{-1}$ ), $\mathrm{H}+\mathrm{Al}$ (extractor calcium acetate $\left.0.5 \mathrm{~mol} \mathrm{~L}^{-1}\right), \mathrm{SB}, \mathrm{CEC}(\mathrm{t})$ and CEC (T) of $2.2 \mathrm{cmol} \mathrm{dm}_{\mathrm{c}}^{-3} ; 0.7 \mathrm{cmol}_{\mathrm{c}} \mathrm{dm}^{-3} ; 0 \mathrm{cmol}_{\mathrm{c}} \mathrm{dm}^{-3}$; $6.44 \mathrm{cmol}_{\mathrm{c}} \mathrm{dm}^{-3} ; 3.15 \mathrm{cmol}_{\mathrm{c}} \mathrm{dm}^{-3} ; 3.15 \mathrm{cmol}_{\mathrm{c}} \mathrm{dm}^{-3}$; and $9.59 \mathrm{cmol}_{\mathrm{c}} \mathrm{dm}^{-3}$, respectively.

The experiment was conducted in a completely randomized design, with three replications. The treatments were organized in a $5 \times 2$ factorial scheme, with the first factor being the types of cultivation (autoclaved and non-autoclaved soil without cultivation and soil from the rhizosphere of Urochloa brizantha, Panicum maximum and Zea mays) and the second factor referring to the absence or presence $\left(240 \mathrm{~g} \mathrm{ha}^{-1}\right)$ of picloram. The three species were cultivated in soil without herbicide residues, for 60 days. After this period, the shoots of the plants were removed and soil samples were collected in the rhizospheric region of each crop, removing five sub-samples, which were homogenized to form a composite sample. A 2-mm-mesh sieve was used to separate the roots from the soil volume collected. The soil that remained adhered to the roots were considered rhizospheric, and therefore collected for analysis (Joergensen 2000). Soil samples without cultivation were also collected to form a sample of this treatment. All the samples were obtained under the same conditions. Subsequently, the samples were sieved (2.0 mm mesh). Half of the soil samples without cultivation were autoclaved for $40 \mathrm{~min}$, at $121{ }^{\circ} \mathrm{C}$, just one time, to reduce the microbial population.

The rhizospheric and non-rhizospheric soils were placed in pots $\left(300 \mathrm{~cm}^{3}\right)$ with diameter of $6 \mathrm{~cm}$ and area equivalent to $60 \mathrm{~cm}^{3}$, representing one experimental unit of $280 \mathrm{~g}$ of soil. A pressurized $\mathrm{CO}_{2}$ sprayer equipped with two TTI 110.02 nozzles, spaced $0.5 \mathrm{~m}$ apart, maintaining a pressure of $200 \mathrm{kPa}$ and a syringe volume of $150 \mathrm{~L} \mathrm{ha}^{-1}$, was used to apply picloram (dose of $1 \mathrm{~L} \mathrm{ha}^{-1}$ of the commercial product - Padron $\left.{ }^{\circledR}\right)$.

One day after the application of the herbicide, $100 \mathrm{~g}$ of soil samples were taken from the vessels and the moisture was adjusted to $80 \%$ of the field capacity, for the evaluation of soil respiration. These samples were placed in a respirometer to evaluate the microbial respiration, microbial biomass carbon and metabolic quotient $\left(q \mathrm{CO}_{2}\right)$ (Reis et al. 2008). Microbial respiration was estimated from the amount 
of $\mathrm{CO}_{2}$ evolved from soil samples of $100 \mathrm{~g}$, captured in flasks containing $10 \mathrm{~mL}$ of $\mathrm{NaOH}\left(0.25 \mathrm{~mol} \mathrm{~L}^{-1}\right)$, in a continuous air flow system (without $\mathrm{CO}_{2}$ and moisture presence). Two flasks without soil were incubated, constituting the blank samples. The soil respiration rate was evaluated at $4,8,12,16,20$ and 24 days of incubation, titrating the $\mathrm{NaOH}$ that did not react with the evolved $\mathrm{CO}_{2}$ of the soil samples with $\mathrm{HCl}\left(0.5 \mathrm{~mol} \mathrm{~L}^{-1}\right)$. After each evaluation, the flasks were replenished with $10 \mathrm{~mL}$ of a $\mathrm{NaOH}$ solution (0.25 $\left.\mathrm{mol} \mathrm{L}^{-1}\right)$.

After 24 days of incubation, $18 \mathrm{~g}$ of soil were removed from each flask to determine the microbial biomass carbon, using the method described by Vance et al. (1987), modified by Islam \& Weil (1998), in which the samples were treated with microwave radiation for a previously calculated time ( $60+60$ seconds). Microbial biomass carbon was extracted from the samples (irradiated and non-irradiated) with $80 \mathrm{~mL}$ of a $\mathrm{K}_{2} \mathrm{SO}_{4}$ solution $(0.5 \mathrm{M})$, in agitation for $30 \mathrm{~min}$ and resting for more $30 \mathrm{~min}$. Posteriorly, the samples were filtered on Whatman paper \# 42. Inside the digester tube, $10 \mathrm{~mL}$ of the filtrate plus reagents were added: $2 \mathrm{~mL}$ of a $\mathrm{K}_{2} \mathrm{Cr}_{2} \mathrm{O}_{7}$ solution $(0.0667 \mathrm{M})$ and $10 \mathrm{~mL}$ of a $\mathrm{H}_{2} \mathrm{SO}_{4}$ solution. The volume was completed with distilled water up to $100 \mathrm{~mL}$, and eight drops of the 1,10 phenanthroline indicator were added. Then, titration with $0.033 \mathrm{~mol} \mathrm{~L}^{-1}$ of a $\left(\mathrm{NH}_{4}\right)_{2} \mathrm{Fe}\left(\mathrm{SO}_{4}\right)_{2}$ solution was carried out until the color changed from yellow to red-vitreous. The values obtained from the evolution of the $\mathrm{C}-\mathrm{CO}_{2}$ and microbial biomass carbon were used to calculate the $q \mathrm{CO} 2$ ( $\mu \mathrm{g} \mathrm{C}-\mathrm{CO}_{2} \mu \mathrm{g}^{-1}$ of microbial biomass carbon $\mathrm{d}^{-1}$ ), dividing the daily means of evolved $\mathrm{C}-\mathrm{CO}_{2}$ by the microbial biomass carbon.

The data were submitted to analysis of variance by the $\mathrm{F}$ test and the means compared by the Tukey test $(\mathrm{p} \leq 0.05)$. Soil respiration over time was carried out through a regression. The models were chosen based on the significance of the regression coefficients, tested by the $t$ test, and on the determination coefficient.

\section{RESULTS AND DISCUSSION}

There was an interaction between the cultivated species and picloram for the evolved $\mathrm{CO}_{2}$. A higher evolved $\mathrm{CO}_{2}$ was observed in the soil cultivated with $Z$. mays in the presence of picloram, what was not verified for the other treatments. There was no difference for evolved $\mathrm{CO}_{2}$ among the species cultivated in the absence of picloram (Table 1).

The evolved $\mathrm{CO}_{2}$, during 24 days of incubation, was influenced by soil type and presence of the herbicide (Figure 1). Among the different types of soil (rhizospheric and non-rhizospheric), there was a higher $\mathrm{CO}_{2}$ evolved in the rhizospheric soil of $U$. brizantha without herbicide application, followed by rhizospheric soil of P. maximum and autoclaved soil without cultivation (Figure 1a).

The soil without cultivation showed a lower evolved $\mathrm{CO}_{2}$ in the absence and in the presence of picloram, if compared to the other soils studied (Figure 1a). The higher evolved $\mathrm{CO}_{2}$ from the autoclaved soil, in relation to the soil without cultivation, may be related to the death of microorganisms by the autoclaving process. This process provides carbon molecules that can be used as source for the microorganisms survival. The lower metabolic activity in non-rhizospheric soil can be explained by the absence of plants. The absence of root exudation from the plants reduces the carbon supply, decreasing the microorganisms community, as well as its activity in non-rhizospheric soils (Sandmann \& Loos 1984, Reis et al. 2008).

Table 1. Average of $\mathrm{CO}_{2}$ evolved in the absence and presence $\left(240 \mathrm{~g} \mathrm{ha}^{-1}\right)$ of picloram, depending on soil cultivation.

\begin{tabular}{lcc}
\hline \multicolumn{1}{c}{ Type of soil cultivation } & Without herbicide & With herbicide \\
\cline { 2 - 3 } & & $\mathrm{CO}_{2}\left(\mu \mathrm{g} \mathrm{g}^{-1}\right.$ of soil day $\left.{ }^{-1}\right)$ \\
\hline Rhizospheric Zea mays & $105.80 \mathrm{aB} *$ & $160.03 \mathrm{aA}$ \\
Rhizospheric Urochloa brizantha & $140.94 \mathrm{aA}$ & $113.06 \mathrm{abA}$ \\
Rhizospheric Panicum maximum & $129.10 \mathrm{aA}$ & $113.44 \mathrm{abA}$ \\
Rhizosphere without cultivation & $112.29 \mathrm{aA}$ & $94.34 \mathrm{bA}$ \\
Autoclaved rhizosphere without cultivation & $122.60 \mathrm{aA}$ & $124.13 \mathrm{abA}$ \\
\hline $\mathrm{CV}(\%)$ & & 18.23 \\
\hline
\end{tabular}

* Means followed by the same lower case letters in the column and upper case letters in the row do not differ by the Tukey test at $5 \%$. 



Figure 1. $\mathrm{CO}_{2}$ evolved in the absence (a) and presence (b) of picloram, from soil cultivated with different species and without cultivation, during 24 days of incubation.

In the rhizospheric soil with maize and in the autoclaved soil without cultivation, there was a higher $\mathrm{CO}_{2}$ evolution in the presence of picloram, if compared to the other soils without herbicide application. The surviving microorganisms in the autoclaved soil can use picloram as a source of carbon in their metabolism, increasing the release of $\mathrm{CO}_{2}$, in relation to the soil cultivated with $U$. Brizantha and $P$. maximum. The competition with other microorganisms present in soils cultivated with these species (U. Brizantha and P. maximum) may limit the activity of those able to metabolize picloram, reducing the evolved $\mathrm{CO}_{2}$.

The higher angular coefficient found in the rhizospheric soil with maize treated with picloram indicates a possible metabolization of the herbicide by soil microorganisms. Similar results were found for soils treated with ametryn, atrazine and glyphosate, where high respiratory rates were obtained in the soils cultivated, when compared to soils without cultivation (Costa et al. 2000, Moreno et al. 2007, Reis et al. 2008). Reis et al. (2008) also observed a higher amount of evolved $\mathrm{CO}_{2}$ in the rhizospheric soils treated with ametryn, trifloxysulfuron-sodium and ametryn + trifloxysulfuron-sodium, if compared to the soil without herbicide application. These herbicides caused an imbalance in the microbial community, inhibiting specific populations and indicating, according to Sakamoto \& Oba (1994), that the microbial biomass of these dead cells was used as a source of $\mathrm{C}$ and energy, increasing the release of $\mathrm{CO}_{2}$.

Besides that, the high concentration of exudates in the rhizospheric region of maize can phytostimulate the microorganisms associated to the rhizosphere, increasing the $\mathrm{CO}_{2}$ evolution in this soil (Santos et al. 2010). Another possibility is associated to the fact that the microorganisms present in the rhizosphere of maize are capable of tolerating and using picloram as a substrate in their metabolism, as it has been reported for Kochia scoparia (Anderson \& Coats 1995, Perkovich et al. 1996) and jack-beans (Canavalia ensiformis), in soil contaminated with atrazine and tebuthiuron, respectively.

High values of evolved $\mathrm{CO}_{2}$ may be an indicative of the adaptation of native microorganisms to the presence of the herbicide (Pires et al. 2005a). However, high soil respiration may not always be related to beneficial effects for the microorganisms. The change in the microbial metabolism and degradation of compounds used as a nutrient source, as well as the intoxication of the soil microorganisms by xenobiotics, decrease the efficiency of carbon utilization, promoting, in both cases, an increase in the $\mathrm{CO}_{2}$ emission (Santos et al. 2007).

The $\mathrm{CO}_{2}$ evolution in the soil cultivated with P. maximum and U. brizantha was similar to the noncultivated soil, showing the lower evolution of $\mathrm{CO}_{2}$ 
in the presence rather than in the absence of picloram (Figures 1a and $1 \mathrm{~b}$ ). This may be an indication that the detoxification of picloram by this species may be associated with the phytodegradation and tolerance exhibited by them to the herbicide (Pires et al. 2005b). According to Pires et al. (2005b), there was no difference in the $\mathrm{CO}_{2}$ evolution between cultivated and non-cultivated soils, when treated with atrazine and tebuthiuron.

Alvey \& Crowley (1996) found similar results for atrazine and tebuthiuron in soils cultivated with Z. mays, Pennisetum americanum and Estizolobium aterrimum. The lower $\mathrm{CO}_{2}$ evolution in the soils cultivated with $P$. maximum and $U$. brizantha may be due to the toxic effect of picloram on the microorganisms, reducing the soil respiration.

There was no interaction between the type of soil cultivation and the presence or absence of the herbicide on the microbial biomass carbon (Table 2). The alteration of the microbial biomass carbon depends on several factors, such as herbicide and dose applied, soil type, species cultivated and their interactions with the soil microorganisms, however, the herbicide application does not always lead to changes in the microbial biomass carbon (Reis et al. 2008).

Only the cultivation with maize influenced the microbial biomass carbon of the soil samples, with a greater value of microbial biomass carbon being observed in relation to the others treatments (Table 2). Herbicides can decrease or increase the microbial biomass and the respiratory rate, thus, it is not always indicated to estimate the stress effects of the herbicides on soil microorganisms through only these two parameters (Reis et al. 2008). In this case, it is recommend using other evaluations, such as the metabolic quotient $\left(q \mathrm{CO}_{2}\right)$, once the results obtained from the relationship between the evolved $\mathrm{CO}_{2}$ and total microbial biomass carbon per unit of time are more representative. The lower values of $q \mathrm{CO}_{2}$ are related to the higher stability of the microbial biomass carbon and organic matter in the soil, i.e., the $\mathrm{C}$-carbon that is not lost as $\mathrm{CO}_{2}$ by respiration, being incorporated into microbial tissues (Anderson \& Coats 1995, Reis et al. 2008).

The rhizospheric soil with maize showed a lower metabolic quotient, indicating a greater stability of the microbial biomass associated with this species (Table 2). Some studies have shown higher values of $q \mathrm{CO}_{2}$ in soils submitted to herbicide application, i.e., a lower efficiency in the use of $\mathrm{C}$ by edaphic microorganisms (Santos et al. 2007 and 2010). However, in this study, a significant difference was not observed in the values of $q \mathrm{CO}_{2}$ when picloram was applied (Table 2).

The herbicide application altered the evolved $\mathrm{CO}_{2}$, but the isolated analysis of this parameter does not provide solid conclusions about the effects of picloram on the soil microorganisms. However, the picloram application did not affect the microbial biomass carbon and $q \mathrm{CO}_{2}$ in the rhizospheric soils of the plants, indicating that the rhizosphere of these species can contribute to decontamination of soils treated with picloram.

Rhizospheric soils with maize showed a greater microbial activity in the presence of picloram than in the rhizosphere of $P$. maximum and $U$. brizantha, suggesting a lower contribution of the rhizosphere of these species to the picloram degradation. This indicates that the vegetal species affects the

Table 2. Microbial biomass carbon (MBC) and metabolic quotient $\left(q \mathrm{CO}_{2}\right)$ after the application of picloram in rhizospheric and non-cultivated soils, after incubation for 24 days.

\begin{tabular}{|c|c|c|}
\hline \multirow{2}{*}{ Type of soil cultivation } & $\mathrm{MBC}$ & $q \mathrm{CO}_{2}$ \\
\hline & $\mu \mathrm{g} \mathrm{g}^{-1}$ of soil & $\mu \mathrm{g} \mathrm{g}^{-1}$ of $\mathrm{CO}_{2}^{-1}$ per $\mu \mathrm{g} \mathrm{g}^{-1}$ of $\mathrm{MBC}$ \\
\hline Rhizospheric Zea mays & $266.80 \mathrm{a}^{*}$ & $0.50 \mathrm{~b}$ \\
\hline Rhizospheric Urochloa brizantha & $161.14 \mathrm{~b}$ & $1.03 \mathrm{ba}$ \\
\hline Rhizospheric Panicum maximum & $159.21 \mathrm{~b}$ & $0.81 \mathrm{ba}$ \\
\hline Rhizosphere without cultivation & $135.57 \mathrm{~b}$ & $1.08 \mathrm{ba}$ \\
\hline Autoclaved rhizosphere without cultivation & $79.61 \mathrm{~b}$ & $1.718 \mathrm{a}$ \\
\hline \multicolumn{3}{|l|}{ Picloram } \\
\hline Absence & $143.39 \mathrm{a}$ & $0.99 \mathrm{a}$ \\
\hline Presence $\left(240 \mathrm{~g} \mathrm{ha}^{-1}\right)$ & $177.54 \mathrm{a}$ & $1.06 \mathrm{a}$ \\
\hline $\mathrm{CV}(\%)$ & 3.79 & 6.160 \\
\hline
\end{tabular}


rhizospheric activity, being able to interfere in the rhizodegradation.

\section{CONCLUSIONS}

1. The cultivation of Zea mays increases the rhizosphere activity;

2. The three plant species affect the microbial activity of the soil, however, the cultivation of Panicum maximum and Urochloa brizantha cause a lower disturbance on the microbial population, when compared to Z. mays.

3. The application of picloran does not affect the biological quality of the soils studied.

\section{ACKNOWLEDGMENTS}

The authors thank the Conselho Nacional de Desenvolvimento Científico e Tecnológico (CNPq), Fundação de Amparo à Pesquisa do Estado de Minas Gerais (Fapemig) and Coordenação de Aperfeiçoamento de Pessoal de Nível Superior (Capes), for financing and supporting this study.

\section{REFERENCES}

ALVEY, S.; CROWLEY, D. Survival and activity of an atrazine-mineralizing bacterial consortium in rhizosphere soil. Environmental Science \& Technology, v. 30, n. 5, p. 1596-1603, 1996.

ANDERSON, T.; COATS, J. Screening rhizosphere soil samples for the ability to mineralize elevated concentrations of atrazine and metolachlor. Journal of Environmental Science \& Health Part B, v. 30, n. 4, p. 473-484, 1995.

ASSIS, R. L. de et al. Phytoremediation of soil contaminated with picloram by Eleusine coracana. Revista Brasileira de Engenharia Agrícola e Ambiental, v. 14, n. 11, p. 11311135, 2010.

BELO, A. F. et al. Atividade fotossintética de plantas cultivadas em solo contaminado com picloram. Planta Daninha, v. 29, n. 4, p. 885-892, 2011.

CARMO, M. L. et al. Seleção de plantas para fitorremediação de solos contaminados com picloram. Planta Daninha, v. 26, n. 2, p. 301-313, 2008.

COSTA, M. A.; MONTEIRO, R. T. R.; TORNISIELO, V. L. Degradação de ametrina em areia quartzosa com adição de solo rizosférrico de cana-de-açúcar. Revista Brasileira de Ciência do Solo, v. 24, n. 1, p. 43-48, 2000.
D'ANTONINO, L. et al. Efeitos de culturas na persistência de herbicidas auxínicos no solo. Planta Daninha, v. 27, n. 2, p. 371-378, 2009.

DELWICHE, K. B.; LEHMANN, J.; WALTER, T. M. Atrazine leaching from biochar-amended soils. Chemosphere, v. 95, n. 1, p. 346-352, 2014.

FERNANDEZ, G.; PITELLI, R. A.; CANADENAZZI, M. Evolução de $\mathrm{CO}_{2}$ e atividades enzimáticas em amostras de solo tratado com herbicidas. Planta Daninha, v. 27, n. 3, p. 601-608, 2009.

FRANCO, M. H. R. et al. Phytoremediation of soils contaminated with picloram by Urochloa brizantha. Pesquisa Agropecuária Tropical, v. 44, n. 4, p. 460-467, 2014.

ISLAM, K.; WEIL, R. Microwave irradiation of soil for routine measurement of microbial biomass carbon. Biology and Fertility of Soils, v. 27, n. 4, p. 408-416, 1998.

JOERGENSEN, R. G. Ergosterol and microbial biomass in the rhizosphere of grassland soils. Soil Biology \& Biochemistry, v. 32, n. 5, p. 647-652, 2000.

MORENO, J. L. et al. Effects of atrazine on microbial activity in semiarid soil. Applied Soil Ecology, v. 35, n. 1, p. 120-127, 2007.

OLIVEIRA, S. P. et al. Fitorremediação de solo contaminado com picloram por capim-pé-de-galinhagigante (Eleusine coracana). Revista Brasileira de Ciência do Solo, v. 32, n. 6, p. 2517-2524, 2008.

PAREJA, L. et al. Occurrence and distribution study of residues from pesticides applied under controlled conditions in the field during rice processing. Journal of Agricultural and Food Chemistry, v. 60, n. 18, p. 44404448, 2012.

PERKOVICH, B. S. et al. Enhanced mineralization of $\left[{ }^{14} \mathrm{C}\right]$ atrazine in Kochia scoparia rhizospheric soil from a pesticide-contaminated site. Pesticide Science, v. 46, n. 4, p. 391-396, 1996.

PIRES, F. R. et al. Inferências sobre atividade rizosférica de espécies com potencial para fitorremediação do herbicida tebuthiuron. Revista Brasileira de Ciência do Solo, v. 29, n. 4, p. 627-634, 2005a.

PIRES, F. R. et al. Fitorremediação de solos contaminados com tebuthiuron utilizando-se espécies cultivadas para adubação verde. Planta Daninha, v. 23, n. 4, p. 711-717, 2005 b.

REIS, M. R. et al. Atividade microbiana em solo cultivado com cana-de-açúcar após aplicação de herbicidas. Planta Daninha, v. 26, n. 2, p. 323-331, 2008.

SAKAMOTO, K.; OBA, Y. Effect of fungal to bacterial biomass ratio on the relationship between $\mathrm{CO}_{2}$ evolution 
and total soil microbial biomass. Biology and Fertility of Soils, v. 17, n. 1, p. 39-44, 1994.

SANDMANN, E.; LOOS, M. Enumeration of 2,4-D-degrading microorganisms in soils and crop plant rhizospheres using indicator media: high populations associated with sugarcane (Saccharum officinarum). Chemosphere, v. 13, n. 9, p. 1073-1084, 1984.

SANTOS, E. A. et al. Atividade rizosférica de solo tratado com herbicida durante processo de remediação por Stizolobium aterrimum. Pesquisa Agropecuária Tropical, v. 40, n. 1, p. 1-7, 2010.

SANTOS, E. A. et al. Phyto-stimulation by Stizolobium aterrimum as remediation of soil contaminated with trifloxysulfuron-sodium. Planta Daninha, v. 25, n. 2, p. 259-265, 2007.

SARMAH, A. K.; MULLER, K.; AHMAD, R. Fate and behaviour of pesticides in the agroecosystem: a review with a New Zealand perspective. Australian Journal of Soil Research, v. 42, n. 2, p. 125-154, 2004.
SILVA, A. A.; SILVA, J. F. Herbicidas: classificação e mecanismo de ação. In: SILVA, A. A.; SILVA, F. A; FERREIRA, L. R. Tópicos em manejo de plantas daninhas. Viçosa: Universidade Federal de Viçosa, 2007. p. 83-148.

SIQUEIRA, J. O.; MOREIRA, F. M. S. Transformações bioquímicas e ciclos dos elementos no solo. In: MOREIRA, F. M. S.; SIQUEIRA, J. O. (Eds.). Microbiologia e bioquímica do solo. Lavras: Editora da UFLa, 2002. p. 305-329.

VANCE, E. D.; BROOKES, P. C.; JENKINSON, D. S. An extraction method for measuring soil microbial biomass C. Soil Biology and Biochemistry, v. 19, n. 6, p. 703-707, 1987.

WHITE, J. C.; NEWMAN, L. A. Phytoremediation of soils contaminated with organic pollutants. In: XING, B.; SENESI, N.; HUANG, P. M. Biophysico-chemical processes of anthropogenic organic compounds in environmental systems. Hoboken: John Wiley \& Sons, 2011. p. 503-516. 